\title{
Quantification of cluster size and low ambient temperature relationships in the honey bee
}

\author{
DW Severson *, EH Erickson Jr ** \\ University of Wisconsin, Department of Entomology, Madison, WI 53706, and \\ US Department of Agriculture, Agricultural Research Service, Bee Research Unit, \\ Madison, WI 53706, USA
}

(Received 8 November 1989; accepted 29 January 1990)

\begin{abstract}
Summary - Cluster volume and surface area were measured over a range of ambient temperatures $\left(T_{a}\right)$ in 3 honey bee colonies representative of small, medium and large populations from 29 November 1984 to 21 March 1985. Changes in these parameters were correlated with changes in $T_{a}$, and the observed response to $T_{a}$ was independent of population size. We observed decreases of about $55 \%$ in cluster volume and $40 \%$ in cluster surface area as the $T_{a}$ decreased from $4{ }^{\circ} \mathrm{C}$ to -23 ${ }^{\circ} \mathrm{C}$.
\end{abstract}

Apis mellffera / cluster size / homeothermy / honey consumption / thermoregulation

\section{INTRODUCTION}

Although the honey bee (Apis mellifera $\mathrm{L}$ ) probably originated in the African or Asian tropics (Ruttner, 1988), present-day descendants living in Europe and other temperate regions have evolved adaptations for thermoregulation which enable successful colonization and survival in extremely cold climates. Survival in cold winter climates is primarily due to their system of food storage and clustering into a tight mass thereby reducing heat loss. Adapta- tion to cold climates does not involve a state of dormancy or hibernation characteristic of most insects; honey bees remain active within the winter cluster. The cluster center, or core, in broodless colonies is generally maintained within the range of 20-30 ${ }^{\circ} \mathrm{C}$ (Gates, 1914; Wilson and Milum, 1927; Corkins, 1930; Owens, 1971, Szabo, 1985, 1989). During brood rearing, core temperatures range from $29-36{ }^{\circ} \mathrm{C}$ (Owens, 1971; Szabo, 1985). The cluster periphery remains relatively isothermal at ca $9^{\circ} \mathrm{C}$ (Owens, 1971; Southwick, 1988).

\footnotetext{
* Present address: Department of Veterinary Science, University of Wisconsin, Madison, Wisconsin 53706, USA

** Present address: USDA-ARS, Carl T Hayden Bee Research Center, 2000 East Allen Road, Tucson, AZ 85719, USA
} 
Research, relative to low ambient temperature $\left(T_{a}\right)$ survival, has generally concentrated on the role of metabolism ( $i e$, honey consumption for heat production) in colony-level thermoregulation. Evidence suggests that increased levels of metabolism are indeed associated with exposure to cold temperatures. Free and Simpson (1963) reported that cluster $\mathrm{CO}_{2}$ production is minimal at about $10^{\circ} \mathrm{C}$ and increases above or below this temperature. Measurements of cluster $\mathrm{O}_{2}$ consumption support these results (Southwick and Mugaas, 1971; Southwick, 1982, 1983, 1985a, 1985b, 1988).

Individual bees (Free and SpencerBooth, 1960) and small groups of bees (Cayhill and Lustick, 1976) are unable to efficiently thermoregulate when subjected to cold temperatures and soon perish. However, an intact cluster within a nest can, effectively thermoregulate, and has been likened to a homeothermic superorganism (Southwick, 1983). It has been suggested that temperature-mediated alterations of cluster dimensions may maximize conservation of heat produced by bees within the cluster (Corkins, 1932; Simpson, 1961; Heinrich, 1981; Severson and Erickson, 1985). However, it has also been suggested that no precise relationship exists between cluster expansion and contraction with the $T_{a}$, and that the limits of cluster contraction are reached at about $0-5{ }^{\circ} \mathrm{C}$ (Seeley and Heinrich, 1981; Southwick, 1988). However, this hypothesis is, based on cursory observations of cluster activity (Gates, 1914; Owens, 1971; Szabo, 1985). In this study, we provide the first quantitative evidence for a relationship between changes in cluster volume and surface area and $T_{a}$ in honey bee colonies.

\section{MATERIALS AND METHODS}

\section{Data collection}

This study was conducted at Madison, WI, USA from 29 November 1984 to 21 March 1985. Three honey bee colonies (Italian-type), representative of small (SP), medium (MP) and large (LP) populations were selected for periodic monitoring of cluster volume and surface area. Estimates of population sizes in November were 18, 40 , and 65 thousand bees, respectively. These estimates were based on comparisons of test colony volume measurements at $4^{\circ} \mathrm{C}$ to those observed among colonies in a related study, in which the entire worker bee population was collected and counted following volume measurement (Severson and Erickson, unpublished data). All colonies consisted of 12-comb, 16.5 $\mathrm{cm}$-deep, square $(50.5 \mathrm{~cm})$ hive-bodies; the SP and MP colonies were maintained in 3 hivebodies, while the LP colony was maintained in 4 hive-bodies. Individual colony lower entrances were closed and an upper entrance $(2.54 \mathrm{~cm}$ auger hole) provided.

The first data were collected on 29 November 1984; the $T_{a}$ was sufficiently low $\left(4^{\circ} \mathrm{C}\right)$, so the clusters were well-defined at this time. The $T_{a}$ was always recorded at the apiary site $(e \mathrm{~g}$, at a single point within about $2 \mathrm{~m}$ from the individual colony locations) immediately prior to cluster measurements. Initial data collection involved separating the hive-bodies of each colony, and when the cluster extended from top to bottom of a hive-body, measuring cluster diameters at the top and bottom of each. Cluster depth in the topmost arid lowest occupied hive-body was also measured. Thereafter, these measurements were gathered from intact colonies using a Volpi type $\mathbf{5 1 5 0 0}$ intrascope (a fiber optics wand) equipped with a red filter. The use of this unit under red light conditions allowed visual determination of cluster location with minimal cluster perturbation. To facilitate data collection with this unit, 2 rows of $0.9 \mathrm{~cm}$ holes were drilled through the hive-bodies (from and back) between each comb: 
- up $1.5 \mathrm{~cm}$ from the bottom of each hivebody; and

- along the center of each hive-body. The holes were then plugged with corks. During data collection, individual corks were removed and the fiber optics wand inserted to the edge of the cluster, and the minimum insertion length was recorded (e g, the minimum distance between the cluster and the hive wall). Such measurements from the front and back of a colony allowed determination of cluster diameter (length). Diameter from side-to-side (width) was measured by examining comb interspaces and determining how close to each side the cluster extended: When a cluster did not extend from top to bottom of a hive-body (as was occasionally observed in the topmost and lowest occupied hive-bodies), the cluster depth within that hive-body was recorded. These measurements generally defined a series of ellipses which were used to calculate cluster volume and surface area (fig 1).

\section{Data analyses}

Statistical analyses were made using the Statistical Analyses System (SAS) for computer data analyses. Percent reduction values for volume and surface area were determined by comparing an observation at a given $T_{a}$ to the respective initial observation on 29 November 1984 $\left(4^{\circ} \mathrm{C}\right)$. However, the data were influenced by the extreme cold weather which occurred between 20 January (d 69) and 2 February 1985 (d 82) (fig 2). The observed cluster response to temperature suggested that sufficient mortality levels had occurred to reduce colony population sizes during this period. Since the response to temperature was based on the original population size, percent reduction values observed atter d 82 (post-cold weather) remained consistently higher than those collected before $d 69$ (pre-cold weather). Therefore, data collected between days 69 and 82 were not utilized in modeling cluster response to $T_{a}$. Furthermore, extensive population loss was observed in the SP colony on 18 February due to starvation; data collected from this colony after ihis date were also not utilized in the development of empirical models.

A nonlinear (NLIN) procedure was used to develop empirical models for the observed relationships between the $T_{a}$ and :

- percent volume reduction; and

- percent surface area reduction.
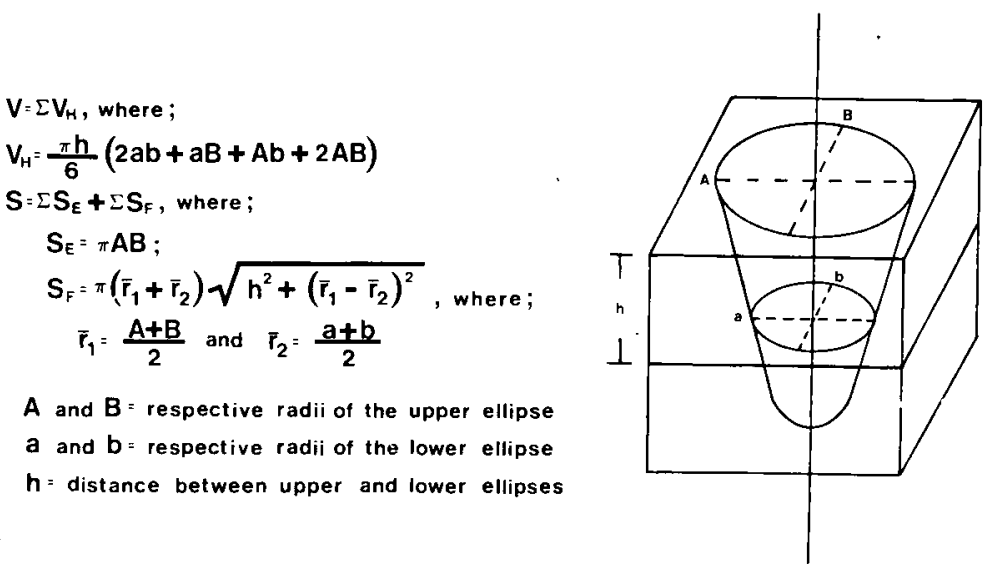

Fig 1. Equations for calculating cluster volume $(V)$ and surface area (S). The equation for $V$ is taken from Severson and Erickson (1984). $V_{H}=$ the cluster volume in 1 hive-body. $S_{E}$ is the standard equation for measuring the surface area of an ellipse; it was used to determine the surface areas of the cluster top and bottom whenever these surfaces were relatively flat. $S_{F}$ is a modification of the equation for determining the area of the curved surface of a frustum of a right cone (Selby and Girling, 1965); it was used to estimate the surface area of the cluster perimeter in each hive-body. 


\section{WINTER $1984-85$}

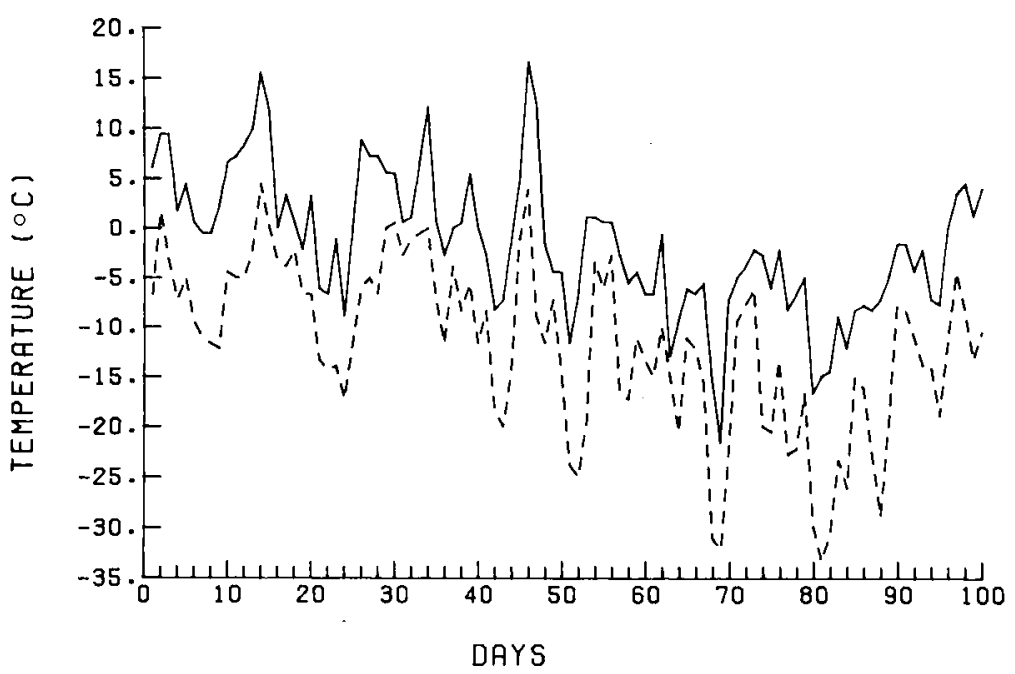

Fig 2. Maximum (solid line) and minimum (broken line) temperatures observed from 12 November 1984 (d 0) to 18 February 1985 (d 98).

To account for the observed reduction in population sizes between days 69 and 82 , an indicator or dummy variable (Severson et al, 1987, for an in-depth explanation on the use of indicator variables) was included in the analyses. Briefly, the use of an indicator variable allowed us to fit our data to equations where the intercept values depended upon the period of sample collection (pre-cold versus post-cold).

\section{RESULTS}

Exponential models, representing the best fit (least squares criterion) to the observed data sets, were derived to describe cluster response to $T_{a}$ in terms of percent:

- volume reduction; and

- surface area reduction.

Cluster percent volume reduction $(V)$ increased as $T_{a}$ decreased, following the equation: $V=58.16\left(1-e^{-0.118(4-T a)}\right)+$ 15.77 ( I) (table I). Cluster percent surface area reduction $(S)$ increased as $T_{a}$ de- creased, following the equation: $S=44.44$ $\left(1-e^{-0.86(4-T)}\right)+11.33(I)$ (table II). The indicator variable (I) was set equal to 1 for data collected after d 82 otherwise $I=0$. Cluster response to $T_{a}$ was independent of colony size although the 3 colonies represented extremes in population size, the observed responses to $T_{a}$ were identical. An ability to reduce volume and surface area reduction values was clearly evident to at least $-23^{\circ} \mathrm{C}$. The use of an indicator variable (I), to account for the observed coldweather decrease in population sizes, demonstrated that cluster response to $T_{a}$ was the same before 19 January (pre-cold weather) and after 4 February (post-cold weather).

\section{DISCUSSION}

Our results indicate that the honey bee winter cluster expands and contracts in a 
Table I. Cluster volume ( $\mathrm{cm} 3$ ) and volume reduction (\%) relative to ambient temperature (Ta).

a Percent reduction was arbitrarily set at zero relative to the initial measurements at $4{ }^{\circ} \mathrm{C}$; b Pre-cold weather data were collected from 29 November 1984 to 19 January 1985. c Post-cold weather data were collected from 4 February to 26 March 1985 . ${ }^{d}$ No data. ${ }^{\ominus}$ Data not included as SP colony experienced extensive population loss due to starvation on 18 February.

\begin{tabular}{|c|c|c|c|c|c|c|c|}
\hline \multirow[b]{2}{*}{ Date } & \multirow[b]{2}{*}{$T_{a}$} & \multicolumn{2}{|c|}{$S P$} & \multicolumn{2}{|c|}{$M P$} & \multicolumn{2}{|c|}{$L P$} \\
\hline & & $\mathrm{cm}^{3}$ & $\%$ & $\mathrm{~cm}^{3}$ & $\%$ & $\mathrm{~cm}^{3}$ & $\%$ \\
\hline \multicolumn{8}{|l|}{ Pre-cold: $b$} \\
\hline 9 November 1984 & 4 & 12800 & $0^{a}$ & 29859 & $0^{a}$ & 49492 & $0^{a}$ \\
\hline 10 January 1985 & -5 & 7163 & 44.00 & $-d$ & - & - & - \\
\hline 11 January 1985 & -8 & 7074 & 44.73 & - & - & - & - \\
\hline 14 January 1985 & -6 & 7644 & 40.28 & - & - & 28671 & 42.07 \\
\hline 15 January 1985 & -15.5 & 6236 & 51.28 & - & - & 25530 & 48.42 \\
\hline 16 January 1985 & -9 & 7301 & 42.96 & 16038 & 46.29 & 26969 & 45.51 \\
\hline 18 January 1985 & -8 & 7162 & 44.05 & 16452 & 44.90 & 25592 & 48.29 \\
\hline 19 January 1985 & -23 & 5343 & 58.26 & 11260 & 62.29 & 21979 & 55.59 \\
\hline \multicolumn{8}{|l|}{ Post-cold: c } \\
\hline $\begin{array}{l}4 \text { February } 1985 \\
6 \text { February } 1985\end{array}$ & $\begin{array}{l}-19 \\
-12\end{array}$ & $\begin{array}{l}3413 \\
4708\end{array}$ & $\begin{array}{l}73.34 \\
63.22\end{array}$ & $\begin{array}{r}8775 \\
12145\end{array}$ & $\begin{array}{l}70.61 \\
59.33\end{array}$ & $\begin{array}{l}17230 \\
16702\end{array}$ & $\begin{array}{l}65.19 \\
66.25\end{array}$ \\
\hline 19 February 1985 & -6.5 & $+\theta$ & + & 14030 & 53.01 & 22265 & 55.01 \\
\hline 20 February 1985 & -2.25 & + & + & 15626 & 47.67 & 27593 & 44.25 \\
\hline 22 February 1985 & 2.5 & + & + & 19694 & 34.04 & 29948 & 39.49 \\
\hline 25 February 1985 & -0.75 & + & + & 17862 & 40.18 & 36043 & 27.17 \\
\hline 26 February 1985 & -2.25 & + & + & 18196 & 39.06 & 37394 & 24.44 \\
\hline 21 March 1985 & 3.25 & + & + & 22670 & 24.08 & 43485 & 12.14 \\
\hline
\end{tabular}

predictable manner relative to changes in the $T_{a}$. This suggests that individual clusters are able to efficiently regulate heat loss from the cluster surface. In addition, cluster volume and surface area continue to decrease as the $T_{a}$ decreases to at least $-23{ }^{\circ} \mathrm{C}$. We observed decreases of about $55 \%$ in cluster volume and $40 \%$ in cluster surface area as the $T_{a}$ decreased from $4{ }^{\circ} \mathrm{C}$ to $-23^{\circ} \mathrm{C}$.

The observed response of individual clusters to changes in ambient temperature was independent of colony population size. We observed identical changes in relative surface area and volume in clusters consisting of ca 18,40, and 65 thousand bees. This phenomenon would, however, promote differential heat loss relative to population size. As the number of individual bees within the cluster increases, proportionally fewer bees are exposed to $T_{a}$. An equal rate of heat loss per unit of colony population size would only be possible if colonies with smaller populations exhibited greater reductions in cluster size as the $T_{a}$ decreased. Colonies with large populations do, therefore, exhibit a greater ability to maintain cluster core temperature (Free and Spencer-Booth, 1958; Southwick, 1985b, 1987). Moreover, since an object with a small surface area to volume ratio (SV) loses heat at a lower rate than one with a large $S V$, one would expect a large colony (small $S V$ ) to be able to maintain 
Table II. Cluster surface area $\left(\mathrm{cm}^{2}\right)$ and surface area reduction (\%) relative to ambient temperature $\left(T_{a}\right)$. See Table I for descriptions.

\begin{tabular}{|c|c|c|c|c|c|c|c|}
\hline \multirow[b]{2}{*}{ Date } & \multirow[b]{2}{*}{$T_{a}$} & \multicolumn{2}{|c|}{$S P$} & \multicolumn{2}{|c|}{$M P$} & \multicolumn{2}{|c|}{$L P$} \\
\hline & & $\mathrm{cm}^{2}$ & $\%$ & $\mathrm{~cm}^{2}$ & $\%$ & $\mathrm{~cm}^{2}$ & $\%$ \\
\hline \multicolumn{8}{|l|}{ Pre-cold: ${ }^{b}$} \\
\hline 9 November 1984 & 4 & 2834 & 0 & 5130 & 0 & 6922 & 0 \\
\hline 10 January 1985 & -5 & 1901 & 32.92 & - & - & - & - \\
\hline 11 January 1985 & -8 & 2123 & 25.09 & - & - & - & - \\
\hline 14 January 1985 & -6 & 2125 & 22.55 & - & - & 4855 & 29.86 \\
\hline 15 January 1985 & -15.5 & 1961 & 30.80 & - & - & 4610 & 33.40 \\
\hline 16 January 1985 & -9 & 2163 & 23.68 & 3582 & 30.18 & 4707 & 32.00 \\
\hline 18 January 1985 & -8 & 2102 & 25.83 & 3519 & 31.40 & 4481 & 35.26 \\
\hline 19 January 1985 & -23 & 1829 & 35.46 & 2732 & 46.74 & 4178 & 39.64 \\
\hline \multicolumn{8}{|l|}{ Post-cold: c } \\
\hline 4 February 1985 & -19 & 1419 & 49.93 & 2439 & 52.46 & 3643 & 47.37 \\
\hline 6 February 1985 & -12 & 1669 & 41.11 & 2949 & 42.51 & 3490 & 49.58 \\
\hline 19 February 1985 & -6.5 & + & + & 3157 & 38.46 & 4119 & 40.49 \\
\hline 20 February 1985 & -2.25 & + & + & 3332 & 35.05 & 4727 & 31.71 \\
\hline 22 Fobruary 1985 & 2.5 & + & + & 4045 & 21.15 & 5001 & 27.75 \\
\hline 25 February 1985 & -0.75 & + & + & 3734 & 27.21 & 5729 & 17.23 \\
\hline 26 February 1985 & -2.25 & + & + & 3726 & 27.37 & 5869 & 13.77 \\
\hline 21 March 1985 & 3.25 & + & + & 4222 & 17.70 & 6351 & 8.25 \\
\hline
\end{tabular}

high cluster temperatures with a lower metabolic expenditure than would a small colony (large SV). This hypothesis is supported by measurements of colony honey consumption rates: average honey consumption rate per unit of colony size decreases as colony size increases (Free and Racey, 1968; Harbo, 1983; Severson and Erickson, unpublished data).

Permanent reductions in cluster size, indicative of a loss in total population, were observed in each colony following exposure to $T_{a}$ of $-30{ }^{\circ} \mathrm{C}$ or less (during the period between 19 January and 4 February). Individual colonies comprised of at least $13000-15000$ bees can, however, survive exposure to $T_{a}$ of $-80^{\circ} \mathrm{C}$ for short periods (Southwick, 1987). Colony survival during periods of exposure to $T_{q}$ below about $-23{ }^{\circ} \mathrm{C}$ may, therefore, depend largely upon increased heat production.

Since bees within the cluster would not perceive changes in $T_{a}$ before those at the cluster periphery had entered chill-coma, it is likely that the peripheral bees are largely responsible for maintaining cluster homeothermy. Perception of changes in $T_{a}$ and the corresponding alteration of cluster parameters by peripheral bees provides a mechanism for conservation of heat produced by bees within the cluster (Heinrich, 1981).

\section{ACKNOWLEDGMENTS}

We thank $E$ Nordheim for assistance in statistical analyses, and J Harbo, $R$ Jeanne, and $M$ 
Strand for helpful comments on an earlier draft of the manuscript.

\section{Résumé - Quantification des relations} entre la taille de la grappe d'abeilles et les basses températures ambiantes. Le volume et la surface de la grappe d'abeilles ont été mesurés à diverses températures ambiantes $\left(T_{a}\right)$ dans 3 colonies représentant des populations de petite (SP), moyenne (MP) et grande (LP) taille, du 29 novembre 1984 au 21 mars 1985 à Madison, Wisconsin (USA). Pour calculer le volume et la surface de la grappe, on a mesuré son diamètre et sa profondeur à l'intérieur des corps de ruche (fig 1). Les valeurs ont été comparées à celles de la $T_{a}$. Des modèles exponentiels, représentant la meilleure adaptation aux données recueillies, ont été développés pour décrire la réponse de la grappe à la $T_{a}$. Les variations observées dans le taux de réduction du volume (tableau I) et de la surface (tableau II) en fonction de la $T_{a}$ sont indépendantes de la taille de la population. Les taux de réduction du volume $(V)$ et de la surface (S) de la grappe augmentent quand la $T_{2}$ décroît, selon les équations: $V$ $=58,16\left(1-e^{-0,118\left(4-T_{a}\right)}\right)+15,77$ (I) et $S=$ $\left.44,44\left(1-e^{-0,86(4-T}\right)_{a}\right)+11,33$ (I). Nous avons observé une diminution d'environ $55 \%$ du volume et $40 \%$ de la surface de la grappe lorsque la température est passée de $4{ }^{\circ} \mathrm{C} a ̀-23^{\circ} \mathrm{C}$.

Apis mellifica / homéothermie / grappe hivernale / consommation de miel / thermorégulation

Zusammenfassung - Quantifizierung
der Beziehungen zwischen der Größe
der Wintertraube und niedriger
Außentemperatur bei der Honigbiene.
Volumen und Obertläche der

Bienentraube wurden bei den auftretenden Außen- temperaturen $\left(T_{a}\right)$ zwischen 29. November 1984 und 21. März 1985 in Madison, WI, USA, bei drei Bienenvölkern gemessen, die nach ihrer Stärke als schwach, mittel und stark gelten konnten. Um Volumen und Oberfläche zu berechnen, wurden Durchmesser und Tiefe der Traube in den Kästen gemessen (Abb 1). Die Werte wurden anschließend mit der $T_{a}$ verglichen. Es wurden exponentielle Modelle mit der besten Anpassung an die beobachteten Daten abgeleitet, um die Reaktion der Traube auf die $T_{a}$ zu beschreiben. Die beobachteten Verände- rungen in der prozentuellen Verringerung von Volumen und Oberfläche in Bezug auf die $T_{a}$ waren unabhängig von der Volksstärke. Die prozentuelle Reduktion des Volumens der Traube (V) stieg mit fallender $T_{a}$ nach folgender Gleichung an: $V=58,16\left(1-e^{-0,118}\left(4-T_{a}\right)\right)$ $+15,77$ (I). Die prozentuelle Reduktion der Trauben- oberfläche (S) nahm nach folgender Gleichung mit abnehmender $T_{a}$ zu: $S=44,44\left(1-\mathrm{e}^{-0,86\left(4-\mathrm{T}_{\mathrm{a}}\right)}\right)+11,33(I)$. Wir beobachteten Abnahmen des Trauben- volumens um etwa $55 \%$ und der Traubenoberfläche um $40 \%$ wenn die $T_{a}$ von $4^{\circ} \mathrm{C}$ auf $-23^{\circ} \mathrm{C}$ absank.

\section{Apis mellifera / Homeothermie / Wintertraube / Honigkonsum /}

Temperatur-Regulierung

\section{REFERENCES}

Cayhill K, Lustic S (1976) Oxygen consumption and thermoregulation in Apis mellifica workers and drones. Comp Biochem Physiol 55A, 355-357

Corkins CL (1930) The metabolism of the honey bee during winter. Wyo Agric Exp Stn Bull $175,1-26$

Corkins CL (1932) The temperature relationships of the honey bee cluster under con- 
trolled external temperature conditions. J Econ Entomol 25, 820-825

Free JB, Spencer-Booth Y (1958) Observations on the temperature regulation and food consumption of honeybees (Apis mellifera). $J$ Exp Biol 35, 930-937

Free JB, Spencer-Booth Y (1960) Chill-coma and cold death temperatures of Apis mellifera. Entomol Exp Appl 3, 222-230

Free JB, Simpson J (1963) The respiratory metabolism of honey-bee colonies at low temperatures. Entomol Exp App/ 6, 234-238

Free JB, Racey PA (1968) The effect of the size of honeyber colonies on food consumption, brood rearing and the longevity of the bees during winter. Entomol Exp Appl 11, 241-249

Gates BN (1914) The temperature of the bee colony. US Dep Agric Bull Agric Inf 96, 1-29

Harbo JR (1983) Effect of population size on worker survival and honey loss in broodless colonies of honey bees, Apis mellifera $L$ (Hymenoptera: Apidae). Environ Entomol 12, 1559-1563

Heinrich B (1981) The mechanisms and energetics of honeybee swarm temperature regulation. J Exp Biol 91, 25-55

Owens CD (1971) The thermology of wintering honey bee colonies. US Dep Agric Tech Bull 1429, 1-32

Ruttner F (1988) Biogeography and Taxonomy of Honey Bees. Springer, Berlin

Seeley T, Heinrich B (1981) Regulation of temperature in the nests of social insects. $I n$ : $/ n$ sect Thermoregulation (Heinrich B, ed) John Wiley and Sons, New York

Selby SM, Girling B (1965) Standard Mathematical Tables. Chemical Rubber Co, Cleveland, Ohio

Severson DW, Erickson EH Jr (1984) Honey bee (Hymenoptera: Apidae) colony performance in relation to supplemental carbohydrates. J Econ Entomol 77, 1473-1478

Severson DW, Erickson EH Jr (1985) Honey consumption by honey bee colonies in rela- tion to winter degree-day accumulation. $A m$ Bee J 125, 643-644

Severson DW, Nordheim EV, Erickson EH Jr (1987) Variation in nectar characteristics within soyabean cultivars. J Apic Res 26 , 156-164

Simpson J (1961) Nest climate regulation in honey bee colonies. Science 133, 1327-1333

Southwick EE (1982) Metabolic energy of intact honey bee colonies. Comp Biochem Physiol 71A, 277-281

Southwick EE (1983) The honey bee cluster as a homeothermic superorganism. Comp Biochem Physiol 75A, 641-645

Southwick EE (1985a) Bee hair structure and the effect of hair on metabolism at low temperature. J Apic Res 24, 144-149

Southwick EE (1985b) Allometric relations, metabolism and heat conductance in clusters of honey bees at cool temperatures. J Comp Physiol 156B, 143-149

Southwick EE (1987) Cooperative metabolism in honey bees: an alternative to antifreeze and hibernation. J Therm Bio/ 12, 155-158

Southwick EE (1988) Thermoregulation in honey-bee colonies. In: Africanized Honey Bees and Ber Mites (Needham GR, Page RE Jr, Delfinado-Baker M, Bowman C, eds) Ellis Horwood, Chichester

Southwick EE, Mugaas JN (1971) A hypothetical homeotherm: the honeybee hive. Comp Biochem Physiol 40A, 935-944

Szabo TI (1985) The thermology of wintering honeybee colonies in 4-colony packs as affected by various hive entrances. $J$ Apic Res 24, 27-37

Szabo TI (1989) Thermology of wintering honeybee colonies in 4-colony packs. I. The direct effects of hive insulation on colony temperatures. Am Bee J 129, 338-339

Wilson HF, Milum VG (1927) Winter protection for the honey bee colony. Wis Agric Exp Stn Res Bull 75, 1-47 